\title{
Study of the Organization of Fodder Exploitation, in the Face of Development Dynamics and the Galloping Urbanization of the City of Abidjan
}

\author{
Mangara Ali $^{1}$, Kouassi Akossoua Faustine ${ }^{2}$, Yéo Yacouba ${ }^{1}$
}

\author{
${ }^{1}$ U.F.R des Sciences de la Nature, Université Nangui Abrogoua (Côte d'Ivoire) \\ ${ }^{2}$ Centre National de Floristique de l'U.F.R. Biosciences, Université Félix Houphouët-Boigny (Côte d'Ivoire)
}

\begin{abstract}
The objective of this study was to analyze the functioning of fodder exploitation in the District of Abidjan. Research and surveys were carried out among fodder operators on both fodder collection and sale spots and on livestock markets as well. Formal surveys, carried out in a single visit using questionnaires, made it possible to conduct interviews with stakeholders. The fodder supply sites include the localities of Alépé, Azaguié, Bonoua, Dabou, Grand-Bassam, Jacqueville and Songon, which are 5 to 60 away from Abidjan. The investigations revealed that $88 \%$ of fodder operators are not members of any trade union, compared to $12 \%$ who are members of the livestock sellers' union. The fodder delivered is usually fresh and bundled or stored in the form of a pile for better conservation before delivery. Concerning the perception of the stakeholders, the threat of disappearance of fodder at the level of the sampling sites, due to the rapid urbanization of Abidjan, is the main concern for the collectors. The lack of organization of stakeholders in terms of transport, the conservation of unsold fodder, the lack of fixed sites for collection, the sale of fodder and the payment of certain taxes, make this activity less beneficial. It is therefore necessary that the players in this sector get better organized to ensure the sustainability of the city's fodder supply and that research for the safeguard and appropriate management of endangered species be undertaken to support the players.
\end{abstract}

Keywords: Fodder, Livestock, Exploitation, Collector, Côte d'Ivoire

\begin{abstract}
Introduction
In Africa, animal husbandry is of paramount importance. For example in Mali, it represents more than $31 \%$ of the primary sector and about $10 \%$ of the national gross domestic product (F.A.O., 2004). In Burkina Faso, it occupies a large segment of the working population and provides livelihoods for many households (Sanon et al., 2018).
\end{abstract}

In Côte d'Ivoire, livestock farming is considered by a large part of the population as a secondary activity to the detriment of other agricultural activities (Aubin, 2004, Kouassi, 2013). Although livestock farming in general is very little developed (Balami, 2003), Abidjan, the economic capital of the country, has significant livestock farming activities in the city and its surroundings (CIPEA, 1979; Yapi-Gnaoré et al., 1996; Kouassi, 2013).

Livestock in the city of Abidjan is undoubtedly an income-generating activity. However, a major constraint in this activity in the capital remains animal feed. Indeed, the development dynamics of the city and the strong urbanization cause pressure, even the disappearance of fodder supply and animal grazing sites (Ali et al., 2003; Kouassi et al., 2010; Kouassi, 2013). The problem of feeding animals, commonly mentioned by some breeders (Sanon et al., 2014), arises crucially in urban areas where there is a lack of space for pasture (Ali et al., 2003; Sanou et al., 2011; Kouassi et al., 2014). According to Kouassi et al. (2010), the source of food for farm animals in the city of Abidjan, consists mainly of available natural fodder resources. Natural meadows are carriers of ecological and environmental values. They constitute an important reservoir of flora and fauna biodiversity, and often have a high fodder value. Thus, this food bank, in particular, farm animals' feed,-has favored the development of a sector of activity made up of fodder operators in natural meadows, across the city, with the aim of feeding animals, but also to generate income for the stakeholders. According to Kouassi (2013), in Abidjan, the supply of fodder to markets is ensured by fodder operators who harvest the plants in several districts of the city and then market them to livestock sellers. For many households, this activity constitutes a significant survival strategy, and an important economic activity in the face of impoverishment and a deterioration in food security, linked to very

This article is published under the terms of the Creative Commons Attribution License 4.0

Author(s) retain the copyright of this article. Publication rights with Alkhaer Publications.

Published at: http://www.ijsciences.com/pub/issue/2021-01/

DOI: 10.18483/ijSci.2412; Online ISSN: 2305-3925; Print ISSN: 2410-4477 
Study of the Organization of Fodder Exploitation, in the Face of Development Dynamics and the Galloping Urbanization of the City of Abidjan

significant urban demographic growth (ArmarKlemesu, 2000 ; Mougeot, 2000).

Thus, in view of the importance of the "fodder exploitation" activity for stakeholders and the effect of urbanization on its development, the need to understand how this activity works appears undeniable for the authorities. It is with this in mind that this study was initiated. The objective of this research is to analyze the functioning of the activity, with a view to contributing to its improvement.

\section{Methodology}

The study was carried out in the district of Abidjan, the economic capital and main city of Côte d'Ivoire, which is located in the south of the country.

Using a qualitative approach, an exploratory study will be carried out through semi-structured interviews with several players in the sector. Open interviews will be carried out with resource persons. After this phase, fodder sale sites will be identified. Municipalities will be visited to locate the fodder disposal sites. Formal surveys will be carried out in a single pass using questionnaires. Thus, interviews will be carried out with stakeholders, both at livestock sale markets, fodder sale outlets and on collection sites in the district of Abidjan.

The survey will consist in questioning the operators on the type of products (species exploited), the distance between the places of collection and sale, the daily frequency of harvest, the different places of supply and sale of fodder, the organization of the sector, the means used, as well as the relations with the supervisory structure (ministry), the type of fodder sold and finally, the perception of the operators as to the existence of an organization or not of the sector.

\section{Data analysis and processing}

The data are coded, entered into Excel before being analyzed. Descriptive statistics (averages, percentages) are applied to the collected data. We subsequently codified the information units made up of information content within the variable. For the variables concerning the perception of fodder operators regarding the organization of the sector, we calculated the trend-impact of the responses using the formula proposed by Leray (2008) which is as follows.

$$
T I=\frac{U I(+)-U I(-)}{U I(+)+U I(-)}
$$

This is the total of positive (favorable) information units minus the total of negative (unfavorable) information units divided by the sum of positive and negative units, multiplied by one hundred. An index is thus obtained, which is either favorable or unfavorable on a scale ranging from -100 to +100 .

\section{Results}

\section{I.1. Forage harvesting sites}

I.1.1. Forage sampling sites

The fodder sold in the city of Abidjan comes from several collection sites both in the city and in periurban areas of the Abidjan district (Alépé, Azaguié, Bonoua, Dabou, Grand-Bassam, Jacqueville and Songon). In Figure 1, the areas speckled in yellow are the main forage harvesting locations. These harvesting sites are 5 to $60 \mathrm{~km}$ away from the Abidjan's cattle market. They are made up of the bush in general, fields, fallow land, around cemeteries, roadsides, abandoned sites and lowlands (Figure 2). Protected areas are also exploited by certain operators, including the Banco National Park's classified forest. The species grow spontaneously in these different places. The most harvested forage species are Panicum maximum, Panicum repens, Commelina benghalensis, Chloris pilosa and Mariscus cylindristachyus. These species are available year round and remain accessible to collectors. 
Study of the Organization of Fodder Exploitation, in the Face of Development Dynamics and the Galloping Urbanization of the City of Abidjan

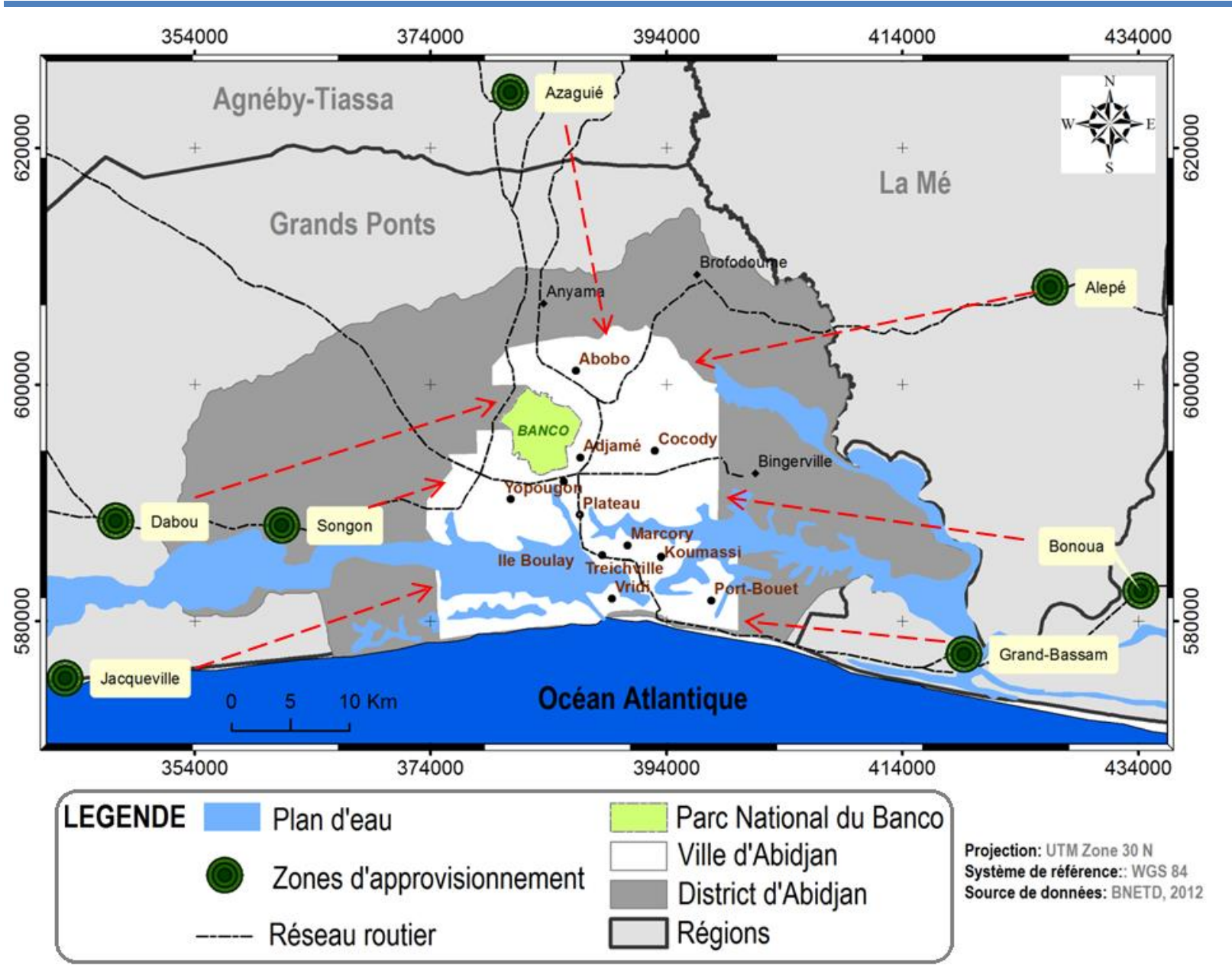

Figure 1: Fodder supply axes for the city of Abidjan

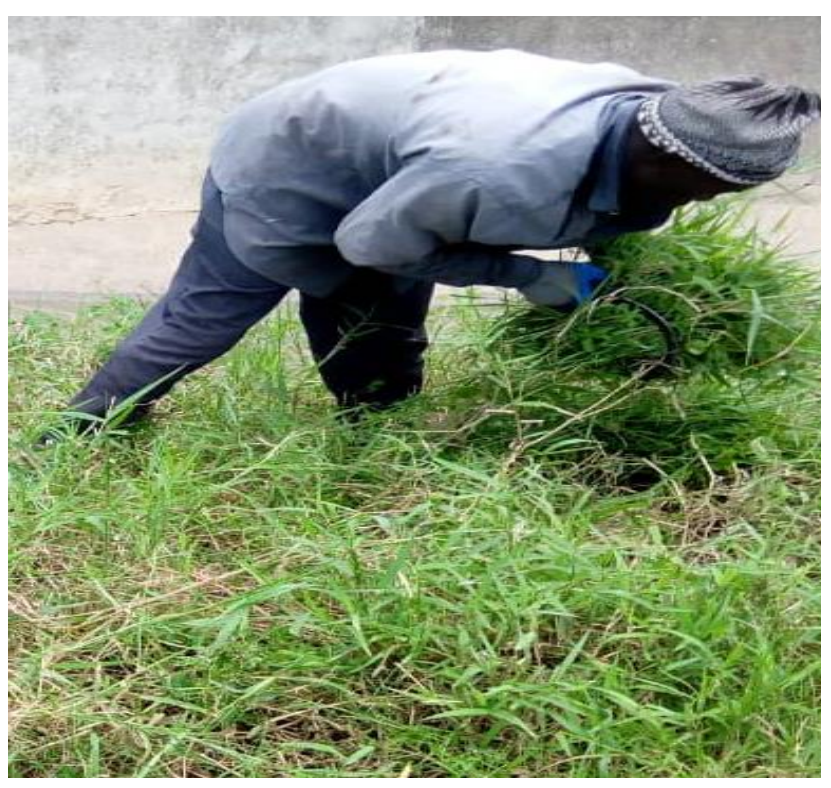

Figure 2: Process of harvesting fodder in a lowland by an operator

\section{I.1.2. Harvested forage flow sites}

The fodder is transported after harvest to the various markets which are largely the markets of the city of Abidjan in addition to a few isolated sites in the city. The livestock markets in the communes of Portbouet, Adjamé, Attécoubé, Abobo and Yopougon were counted. In every one of them, the site listed includes several sales outlets. On average, every livestock market has at least three fodder sales outlets depending on the size of the market and the period (near the holidays, for example). Fourteen fodder sales sites were listed in total. Also, the size of the outflow sites is different from site to site and from one livestock market to another.

It appears that no sales site has been set up. However, we note the presence of a few makeshift shed installed on certain sites. These are made of tarps or straw to keep the fodder safe from bad weather or to provide vendors with shelter from the sun or the rain. Most sites are permanent, and forage sellers often have potential buyers to whom the produce is most often delivered directly. However, during the busy period, we note the presence of occasional sites. 
Study of the Organization of Fodder Exploitation, in the Face of Development Dynamics and the Galloping Urbanization of the City of Abidjan

I.2. Characteristics of the actors and functioning of the sector

A total of 33 fodder marketing players including 14 sellers, 12 collectors and 7 transporters were surveyed.

- Collectors: These are the people who collect the fodder, using sickles, machetes or knives.

- Carriers: these transport fodder from the collection points to the delivery areas using rickshaws, bicycles, tricycles and trucks. Some of these carriers are also collectors.

- Fodder sellers: They are in direct contact with the cattle sellers to whom they sell their products.

The actors in the fodder sector are only made up of men, the majority of whom $(85 \%)$ are married (Table I). For $58 \%$ of the stakeholders surveyed, the marketing of fodder is associated with one or more other activities. The remaining $42 \%$ practice the sale of fodder as their sole activity (Table II). Figure 3 shows the contribution of fodder exploitation to the socio-economic well-being of stakeholders in the sector. According to respondents, the activity covers health care $(60 \%$ of respondents), clothing ( $80 \%$ of respondents), as well as the cost of repairing means of transport (75\% of respondents). As none of the respondents own a house, the activity allows them to pay for the rental of their home ( $90 \%$ of respondents). Moreover, according to $58 \%$ of respondents, the activity of selling fodder allows them to cover the school fees of their children.

Our investigations revealed that $88 \%$ of forage operators are not members of any trade association. The remaining members, $12 \%$ of these farmers, indicated that they were members of the Association of Livestock Vendors. In general, fodder operators, who are most often nationals of countries bordering Côte d'Ivoire, meet at the point of sale during sales, to discuss the problems encountered and to exchange information. Regarding the future of the business, all operators believe that if nothing is done, the forage sampling areas will eventually disappear. For that purpose, they are ready to become involved in an associative framework if they are allocated a space and if possible with technical and financial support. They also consider it necessary to set up a trade union to better organize the sector and ensure its sustainable management.

Table I: Marital status of the stakeholders

\begin{tabular}{|l|c|c|c|c|c|c|c|c|}
\hline Marital status & Collectors & Carriers & \multicolumn{2}{l|}{ Fodder sellers } & Sum & Percentage \\
\hline & Number & $\%$ & Number & $\%$ & Number & $\%$ & Number & $\%$ \\
\hline Married & 10 & 83 & 4 & 57 & 14 & 100 & 28 & 85 \\
\hline Single & 2 & 17 & 3 & 43 & 0 & 0 & 5 & 15 \\
\hline Total & 12 & 100 & 7 & 100 & 14 & 100 & 33 & 100 \\
\hline
\end{tabular}

Table II: Type of activities performed

\begin{tabular}{|l|l|l|l|l|l|l|l|l|}
\hline Other activity & \multicolumn{2}{|l|}{ Collectors } & \multicolumn{2}{l|}{ Carriers } & \multicolumn{2}{l|}{ Fodder sellers } & Sum & Percentage \\
\hline & \multicolumn{1}{|c|}{ Number } & $\%$ & Number & $\%$ & Number & $\%$ & Number & $\%$ \\
\hline Yes & 5 & 42 & 5 & 71 & 9 & 64 & 19 & 58 \\
\hline No & 7 & 58 & 2 & 29 & 5 & 36 & 14 & 42 \\
\hline Total & 12 & 100 & 7 & 100 & 14 & 100 & 33 & 100 \\
\hline
\end{tabular}

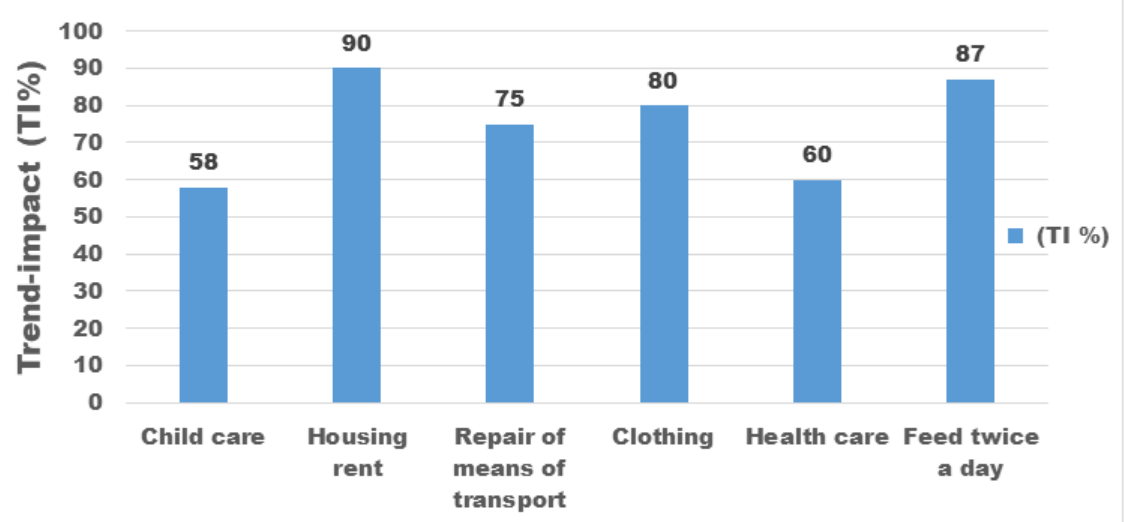

Figure 3: Contribution of fodder exploitation to the socio-economic well-being of stakeholders

\section{I.3. Means of transport of harvested fodder}

The cart is the most used means of transport, i.e. $45 \%$ of transporters, followed by the $36 \%$ tricycle and the
$19 \%$ semi-van as shown in figure 4 . These different means of transport vary from one municipality to another and are also depending on the distance 
Study of the Organization of Fodder Exploitation, in the Face of Development Dynamics and the Galloping Urbanization of the City of Abidjan

between the pick-up location and the delivery location. For example, in the municipality of Abobo, operators generally use tricycles (medium distances), while in Port-Bouët, operators use vehicles more for long distances and carts (rickshaws) for short distances.

To collect fodder, collectors travel distances varying between 5 and $60 \mathrm{~km}$ around the city of Abidjan (Alepé $55.5 \mathrm{~km}$, Grand-Bassam 41.7 km, Dabou 45.8 $\mathrm{km}$ from the city of Abidjan). So they can only make one trip a day. But, concerning the small distances, they manage to make at least two trips per day during the periods of high market demand for livestock.
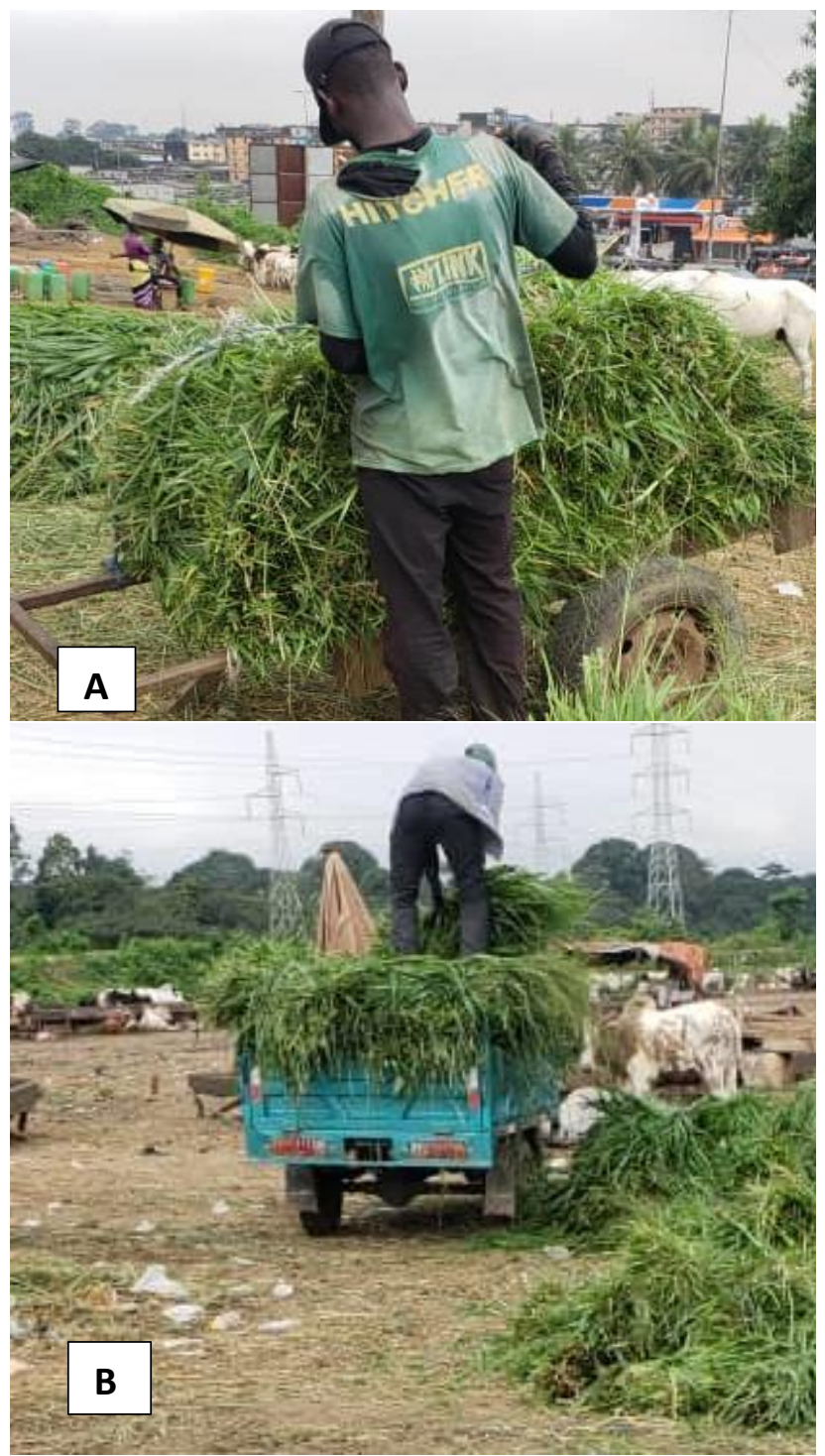

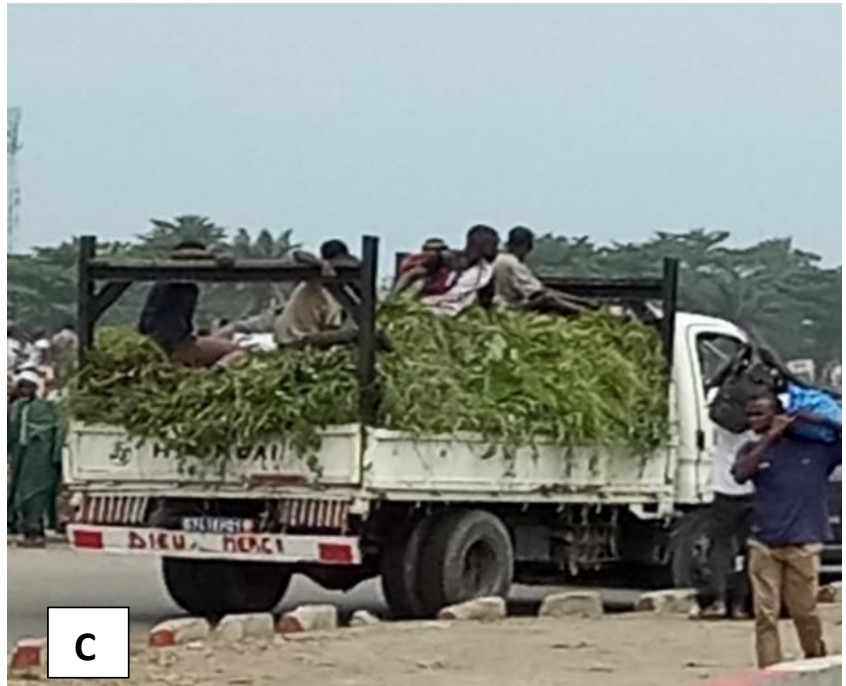

Figure 4: Means of transport of harvested fodder: Cart (A), Tricycle (B), Semi-van (C)

\section{I.4. Types of forage sold and methods of preservation}

The fodder found on cattle markets is of various origins. The fodder delivered is generally fresh and packaged in bundles (Figures 5A) or stored in heaps (Figure 5B) for better preservation prior to delivery.

Fresh grass from natural pastures is the main type of fodder sold by all vendors in the city of Abidjan. This grass is generally intended for sheep and cattle sold in livestock sales markets. The price of the bundle is generally set between 100 and 200 FCFA, depending on supply and demand. As the Tabaski festival approaches, the weight of the bundle decreases considerably, resulting in an increase in its commercial value. Sheep feed comes first in all livestock sales markets with over $70 \%$ of fodder purchased, followed by cattle (Figure 6). Goats are fed more on aerial forage, which is largely made up of the species Ficus exasperata. 
Study of the Organization of Fodder Exploitation, in the Face of Development Dynamics and the Galloping Urbanization of the City of Abidjan

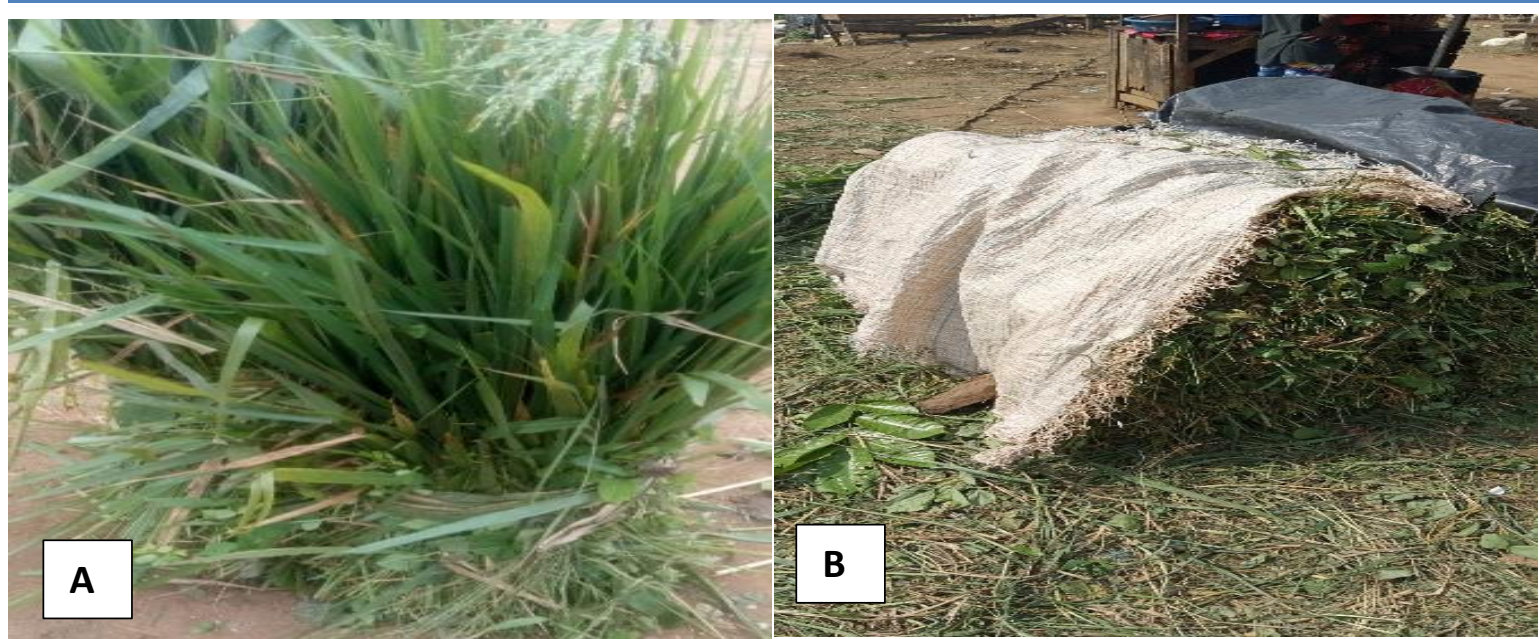

Figure 5 : Fodder packaged in bundles (A) and stored in heaps (B)

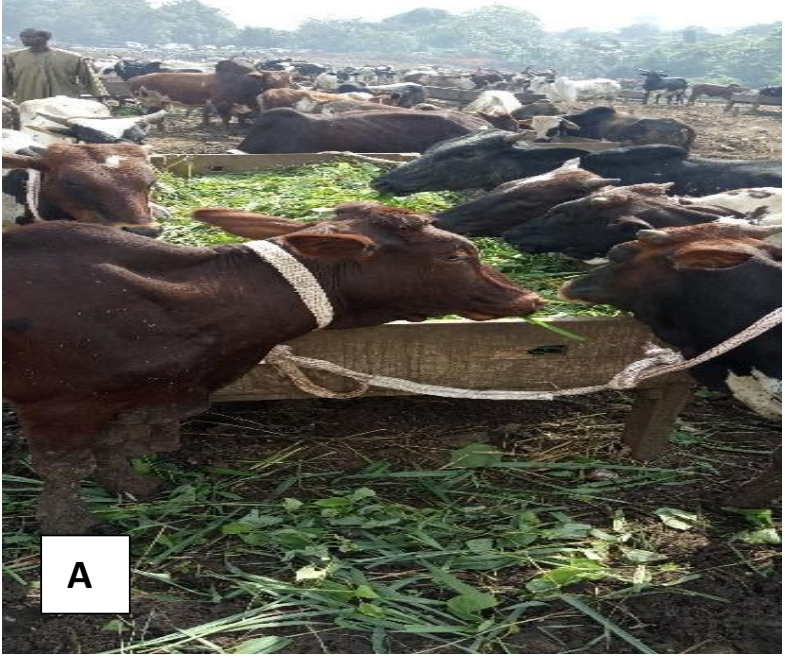

Figure 6: Feeding of cattle (A) and sheep (B)

\section{I.5. Perception of stakeholders regarding the practical organization of the sector}

According to our surveys, stakeholders are aware of the degradation and disappearance of fodder resources. However, some operators show a state of obvious disinterest in the face of this problematic situation. The majority of respondents aged over 40 think it is time to organize and intervene to protect not only the areas with forage species, but also biodiversity in general. Concerning the stakeholders' perception of the means of obtaining fodder plants other than that of spontaneous vegetation, they are thinking of the adoption of a regulation for the exploitation of fodder and the protection of fodder species through capacity building in the management of harvesting areas. Less than $15 \%$ of the stakeholders' think that it would be more judicious to obtain plots to grow fodder in order to avoid several constraints facing their activity. The threat of disappearance of fodder from sampling sites, due to the rapid urbanization of Abidjan, is the main concern for collectors. The lack of organization of stakeholders' in terms of transport, the conservation

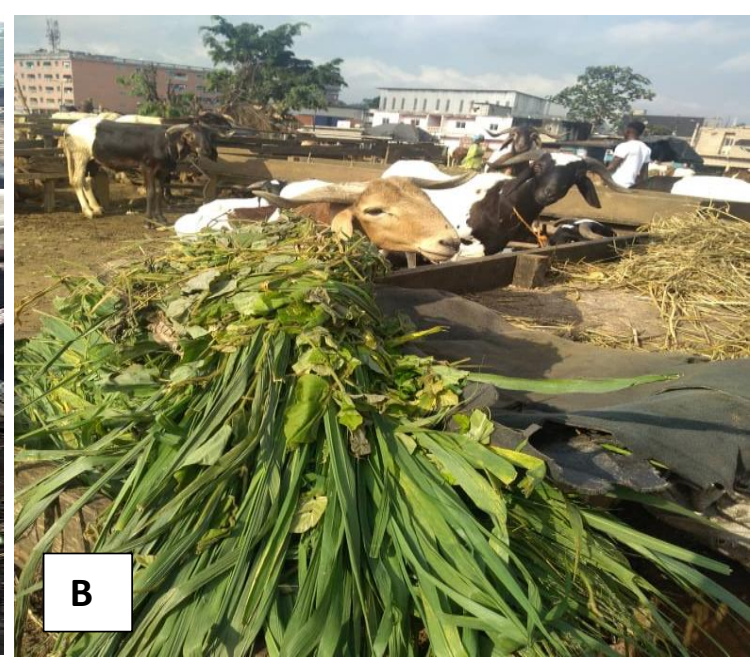

of unsold fodder, the lack of fixed sites for harvests, the sale of fodder and the payment of certain taxes, make this activity not very beneficial and attractive.

\section{Discussion}

The high number of inventoried sites in the city of Abidjan demonstrates the importance of the fodder sales activity. At least 14 fodder outlets have been listed in the various livestock markets in the city of Abidjan. This result is almost identical to that reported by Sanou et al. (2016), who noted 15 permanent fodder sales sites in the city of BoboDioulasso in Burkina Faso. In Côte d'Ivoire, the majority of fodder sales sites are generally found in livestock sales markets (Kouassi et al., 2010). This is different from the fodder sales sites in Burkina Faso where they are located all along the main arteries of the city according to Sanou et al. (2016). This situation could be explained by the fact that in the city of Abidjan, the fodder is generally intended for the cattle present on the cattle markets whereas in Burkina Faso, it is generally the cattle breeders who buy the fodder for feeding their livestock. Also, 
according to respondents, sheep are the first species for which fodder is purchased on livestock sales markets. This is due to the predominance of this group of species on the markets.

The sale of fodder is an activity which is mainly carried out by men. This could be explained on the one hand by the difficulty of collecting fodder, and on the other hand, by the fact that women are more interested in selling other types of animal feed (Soubeiga, 2014 ) such as corn bran, cereals. In Burkina Faso, Sanou et al (2011) found a rate of 93\% of men involved in the exploitation of fodder plants. In Mali, Maman (2014) also noted that men made up $97.67 \%$ of the feed vendor population.

Harvesting fodder is an income-generating activity that contributes to improving the living conditions of households. Also, the activity makes it possible to meet certain expenses of daily life. According to the actors, the main reasons for involvement are poverty and lack of work. The activity allows them to meet the needs of their homes. Aboh (1999) reported on the importance of fodder marketing as an incomegenerating activity in southern Benin with incomes above the guaranteed minimum inter-professional wage (SMIG).

In general, the sale of fodder is not the main activity of those concerned, who mainly practice other types of trade. The proportion of those who make the sale of fodder their main activity is on average $42 \%$. These results are close to those of Sanou et al. (2011) who obtained in their work that only $37 \%$ of people practice the sale of fodder as their only activity. This means that most of the actors carry out this activity in a secondary way (Tegegne et al., 2003).

People in other types of business are also interested in selling fodder. These are, for example, traders, truck unloaders and drivers. For these people, the sale of fodder is a very remunerative activity, especially during periods of Tabaski when this activity is booming. It has been found that Ivorians do not take much interest in livestock activities in general and fodder exploitation in particular (Kouassi, 2013). To earn a living, they prefer other industries.

Regarding the organization of the activity, surveys have shown that the players in the sector do not work in cooperatives, and therefore are not organized. The fodder is sold in a fairly short circuit, since in many cases the collector is at the same time the fodder seller.

All forage operators use some form of transport to supply the market. These different means vary from one municipality to another and also depending on the distance of collection and the point of delivery. The most widely used means of transporting fodder in the city of Abidjan is the cart. This shows that this sector is not yet modernized. Most of those interviewed work alone or work with family members (Maman et al., 2018). Also, the harvesting areas with free access are subject to the galloping development of the city. With the development of urban and peri-urban livestock farming to meet animal production needs in Côte d'Ivoire, increasing amounts of fodder are being exploited and taken to fodder food markets. This situation has a negative influence on the sustainability of fodder resources. This is why it is imperative to draw the attention of stakeholders to the severe degradation of natural fodder resources, or even to the decline or disappearance of certain harvest areas. This means that the various actors must organize themselves to better ensure the management of the sector with the prospect of the establishment of dual-use fodder crops such as Arachis hypogea and Ipomoea batatas. This could constitute a better factor of agriculturelivestock integration (Obulbiga et al., 2015).

\section{Conclusion}

The study provided a better understanding of the functioning of the fodder farming sector in the city of Abidjan. We remember that this is an activity that is quite profitable for the people involved. However, no organization has been put in place for a better management of the sector. The harvesting of fodder is based primarily on the exploitation of natural resources. The need for better organization of stakeholders and especially their awareness to the practice in fodder crops is imperative. This will help protect the environment and the sustainability of their activity in order to avoid long-term adverse consequences on the resources harvested. Also, according to our observations with respondents, the lack of organization of the actors makes the activity less beneficial.

\section{Conflict of interests}

The authors have not declared any conflict of interests

\section{References}

1. Aboh A B, 1999. La commercialisation de fourrages verts au marché de Zongo à Cotonou: état des lieux et contraintes. Bulletin de la Recherche Agronomique, 25 : 1-8.

2. Ali L, Van den Bossche P, Thys E, 2003. Enjeux et contraintes de l'élevage urbain et périurbain des petits ruminants à Maradi au Niger : quel avenir ? Revue Élev. Méd. Vét. Pays Trop., 2003, 56 (1-2) : 73-82. DOI: https://doi.org/10.19182/remvt.9879

3. Armar-Klemesu M, 2000. "Urban Agriculture and Food Security, Nutrition and Health," in Bakker N., Dubbeling M. Gündel S., Sabel-Koshella U., de Zeeuw H., Eds, Growing cities, growing food: Urban agriculture on the policy agenda, Proc. Workshop in La

4. Havana, Cuba, 11-15 October 1999. Feldafing, Germany, 
DSE-ZEL, pp. 99-117.

5. Aubin A, 2004. Introduction de l'élevage de bovin, dans le sud de la Côte d'Ivoire, 86p.

6. Balami D H, 2003. Le rôle de la filière bétail dans la compétitivité des pays ouest-africains. In : Club du Sahel, l'Afrique de l'Ouest et la Mondialisation : les Facteurs de la Compétitivité, pp. 235-257. Biosciences, Université Félix Houphouët Boigny Abidjan, 173 p.

7. C.I.P.E.A., 1979. Centre International pour l'Elevage en Afrique. Monographie 2. Le bétail trypanotolérant d'Afrique Occidentale et Centrale. Tome 1, Situation Générale : Addis Abeba, $155 \mathrm{p}$.

8. F.A.O., 2004. Regional Conference for Africa, Sess. 24 Bamako (Mali), 1-5 Mars 2004.

9. INS, 2015. Recensement général de la population et des habitations 2014, données socio- démographiques des localités. Institut National de Statistiques : Abidjan, Côte d'Ivoire.

10. Kouassi A F, 2013. Étude Agrostologique et Socioéconomique des exploitations fourragères

11. dans les zones urbaines et périurbaines da la ville d'Abidjan (Côte d'Ivoire).Thèse Unique, UFR Biosciences, Université Félix Houphouët Boigny Abidjan, 173 p.

12. Kouassi A F, Majorein V, Ipou Ipou J, Adou Yao C Y, Kamanzi K, 2010. Alimentation des ovins des marchés de vente de bétail dans la ville d'Abidjan, Côte d'Ivoire. Agronomie Africaine, 22 (1): 1- 95 ISSN n $^{\circ}$ 1015-2288.

13. Kouassi A F, Koffi K J, N'goran K S B, Ipou Ipou J, 2014, Potentiel de production fourragère d'une zone pâturée menacée de destruction : cas du cordon littoral Port-Bouët et Grand-Bassam. Journal of Applied Biosciences, 82 : 7403 7410. ISSN $1997-5902$.

14. Leray C, 2008. L'analyse de contenu: de la théorie à la pratique, la méthode Morin Chartier. Presses de l'Université du Québec, Québec, Canada, $180 \mathrm{p}$.

15. Maman Lawal A A, Chaibou M, Mani M, Garba M M Gouro A S, 2018. Pratiques d'éleveurs et résultats économiques d'élevage dans les exploitations urbaines et périurbaines de Niamey. Int. J. Biol. Chem. Sci., 12(1): $294-$ 309. DOI : https://dx.doi.org/10.4314/ijbcs.v12i1.24

16. Maman S, 2014. Analyse du système de commercialisation du Fourrage dans la ville de Niamey (Niger). Mémoire de Master : Productions Animales et Développement Durable. Ecole Inter-états des Sciences et Médecine vétérinaires (EISMV) de Dakar, Sénégal, 40p.

17. Mougeot L J A, 1994. Urban Food production: Evolution, Official Support and Significance, With Special Reference to Africa. Ottawa, Canada, IDRC

18. Mougeot L J A, 2000. Urban agriculture: definition, presence, potential and risks. In: Bakker N. et al., Growing cities, growing food: urban agriculture on the policy agenda, a reader on urban agriculture. Feldafing, Allemagne, Des-Etc, $18 \mathrm{p}$

19. Obulbiga M F, Bougouma V, Sanon H O, 2015 Amélioration de l'offre fourragère par l'association culturale céréale-légumineuse à double usage en zone nord soudanienne du Burkina Faso. Int. J. Biol. Chem. Sci., 9(3): 1431-1439. DOI: http://dx.doi.org/10.4314/ijbcs.v9i3.26

20. Robineau O, 2013. Vivre de l'agriculture dans la ville africaine. Une géographie des arrangements entre acteurs à Bobo-Dioulasso, Burkina Faso. Thèse de doctorat, Géographie et Aménagement de l'Espace. Université Pau Valéry - Montpellier III, France ; 379 p.

21. Sanon H O, Drabo A, Sangaré M, Kiendrebéogo T, Gomgnibou A, 2014. Caractérisation des pratiques d'embouche bovine dans l'Ouest du Burkina Faso. Int. J. Biol. Chem. Sci., $8 \quad$ (2): 536-550.DOI: http://dx.doi.org/10.4314/ijbcs.v8i2.13

22. Sanon H O, Some/Sanou S, Obulbiga M F, Oubda F A et Bamouni I, 2018 Analyse de la structure et du fonctionnement de la filière fourrage dans les villes de Ouagadougou et Bobo-Dioulasso au Burkina Faso. Int. J. Biol. Chem. Sci. 12(3): 1247-1259, ISSN 1997-342X (Online), ISSN 1991-8631 (Print).

23. Sanou K F, Ouédraogo S, Nacro S, Ouédraogo M, KaboréZoungrana C, 2016. Durabilité de l'offre et valeur nutritive des fourrages commercialisés en zone urbaine de BoboDioulasso, Burkina Faso. Cah. Agric., 25, 15002; 10 p. DOI: 10.1051/cagri/2016007.

24. Sanou K F, Nacro S, Ouédraogo M, Ouédraogo S, KaboréZoungrana $\mathrm{C}$, 2011. La commercialisation de fourrages en zone urbaine de Bobo-Dioulasso (Burkina Faso) : pratiques marchandes et rentabilité économique. Cah Agric, 20: 48793. DOI: https://doi.org/10.1684/agr.2011.0530

25. Soubeiga L M, 2014. Analyse des aliments du bétail vendus dans la ville de Ouagadougou: Structure et fonctionnement des marchés. Rapport de stage de fin de cycle de techniciens supérieurs d'élevage. ENESA, Ouagadougou, Burkina Faso, $40 \mathrm{p}$.

26. Tegegne A, Tadesse M, Alemayehu M, Woltedji D, Sileshi Z, 2003. Scoping study on peri-urban and urban livestock production in Addis Ababa, Ethiopia. In Urban livestock keeping in sub-Saharan Africa, Richards JI, Godfrey SH (Eds). Report of a workshop held on 3-5 March 2003 in Nairobi, Kenya. Natural Resources International Ltd, Aylesford, Kent, UK. ISBN: 0-95329274-9-0.

27. Yapi-Gnaoré C V, Oya B A et Ouattara Z, 1996. Revue de la situation des races d'animaux domestiques de Côte d'Ivoire. Animal Genetic Resources Information, 19: 99-118. 